\title{
Carbon and fullerene nanomaterials in plant system
}

\author{
Azamal Husen ${ }^{1 *}$ and Khwaja Salahuddin Siddiqi ${ }^{2}$
}

\begin{abstract}
Both the functionalized and non functionalized carbon nanomaterials influence fruit and crop production in edible plants and vegetables. The fullerene, $C_{60}$ and carbon nanotubes have been shown to increase the water retaining capacity, biomass and fruit yield in plants up to $\sim 118 \%$ which is a remarkable achievement of nanotechnology in recent years. The fullerene treated bitter melon seeds also increase the phytomedicine contents such as cucurbitacin-B (74\%), lycopene (82\%), charantin (20\%) and insulin (91\%). Since as little as $50 \mathrm{mg} \mathrm{mL}^{-1}$ of carbon nanotubes increase the tomato production by about $200 \%$, they may be exploited to enhance the agriculture production in future. It has been observed that, in certain cases, non functionalized multi-wall carbon nanotubes are toxic to both plants and animals but the toxicity can be drastically reduced if they are functionalized.
\end{abstract}

Keywords: Carbon nanomaterials, Uptake, Accumulation, Translocation, Plant growth, Seed germination, Agriculture

\section{Introduction}

History of carbon is difficult to trace although it is as old as human civilization. Charcoal was used for water purification and adsorbent by ancient Hindus in India, and wood charcoal as an adsorbent and purifying agent by Egyptians and Sumerians as early as 3750 to $1500 B C$ [1]. 'Indian inks' made from soot were used in the oldest Egyptian herioglyps on papyrus. Although activated charcoal, an allotrope of carbon is generally used as decolorizing agent in metallurgical operation, the use of carbon nanomaterials has been recognised in the recent years. A wide variety of carbon-based nanomaterials such as fullerene, fullerene cages, single-wall carbon nanotubes (SWCNTs) and multi-wall carbon nanotubes (MWCNTs) have been prepared. Diameters of SWCNTs and MWCNTs are typically between 0.8 to $2 \mathrm{~nm}$ and, 5 to $20 \mathrm{~nm}$ respectively, although MWCNTs diameters can exceed $100 \mathrm{~nm}$. CNTs length ranges from less than $100 \mathrm{~nm}$ to several $\mathrm{cm}$, thereby bridging molecular and macroscopic scales. Fullerenes are cage-like structures comprising of twelve 5-member carbon and unspecified 6-member rings in defect-free form. Even though an

\footnotetext{
* Correspondence: adroot92@yahoo.co.in

'Department of Biology, College of Natural and Computational Sciences, University of Gondar, P.O. Box 196, Gondar, Ethiopia

Full list of author information is available at the end of the article
}

icosahedrally symmetrical structure (nC60) is the most commonly encountered fullerene, both smaller fullerene such as C28 and C36 and very large spherical fullerene conformations have been identified and characterized $[2,3]$.

Carbon nanomaterial and fullerenes have been used as conducting material, optical devices, quantum computer, removal of biological contaminants, molecular switch, tissue engineering, pharmacy and medicine or carrier in drug delivery system [4-11]. Fullerenes and their derivatives are known to be powerful antioxidant in vivo (without much toxicity) and neuroprotecting agents [12-14]. The antioxidant, antiviral and anti cancerous activity of fullerols, $\mathrm{C}_{60}(\mathrm{OH})_{20}$ has been ascribed to suppressed accumulation of superoxide and hydroxyl radical-initiated lipid peroxidation and free radical scavenging.

Carbon nanotubes - field effect transistors have been shown for selective detection of oxidase, dehydrogenase activity and many other enzymes and biomolecules, although it has some limitation $[15,16]$. Carbon nanotubes have been proposed as scaffolding agent for antimicrobial silver nanoparticles [17]. The optical properties of semiconducting SWCNTs has also been explored in photoluminescent detection of protein and selective biomolecules [18-23]. The unfunctionalized raw MWCNTs have been demonstrated to be carcinogenic to mice [24] while appropriately functionalized ones, did not show any 
apparent toxicity both in vitro and in vivo [25-28]. There are many factors which appear to be responsible for the toxicity of carbon nanotubes for instance, (a) hydrophobic nature of nanotubes (b) presence of catalyst and (c) presence of surfactants. Functionalized carbon nanotubes have been used in drug delivery. The cavity provided by hollow nanotubes allows large molecules like mellollocence, complex ions, fullerenes and DNA to be encapsulated [29-31] and delivered to the target cells. It is paradoxical and requires long time experiment before practically putting it to use in living system as a carrier. Application of carbon nanomaterials in agriculture is the basic need of the hour because of increasing population and depleting resources. In the recent years, carbon nanomaterials are used in agriculture to increase the crop production (Table 1). While they are known to be useful in (many cases) seed germination, root growth and photosynthesis there are many other aspects like; uptake and rejection, accumulation and transportation and transmission of nanomaterial in the progeny. If any genetic damage occurs due to forced injection of carbon nano material, it may cause mutation which may be transmitted to the next generation of the plant and, may have unwarranted influence in them. Although, a rapid progress is made in the synthesis and use of carbon nanomaterial their mechanism of interaction with plant is not well understood because conflicting reports from various quarters have been received [32-35].

Since carbon nanotubes can stimulate growth, gene and protein expression of aquaporin in tobacco cells [45] it may also trigger the reproductive genes in similar other plants. The penetration of CNTs into the plant system is inversely proportional to its size and, it is the key factor to increase the plant growth and fruits. Perhaps the large size of activated carbon particles are forbidden to enter the plant cell and therefore, get adsorbed on the surface.

In this review we are summarising the uptake and accumulation of carbon nanotubes, fullerenes and fullerol in edible and crop plants. Also, their effect on rate of germination, increase in biomass, absorption and translocation in different parts of plants has been assessed.

\section{Uptake, translocation and accumulation of carbon nanomaterials}

All nanomaterials suspended in water may be selectively absorbed or rejected by plants but essential plant nutrients are generally absorbed. The carbon nanomaterials may however, be absorbed through roots of the plants but in seeds it may penetrate making a hole of appropriate size and translocated to the shoot. The absorption of carbon nanomaterial depends mainly on its interaction with suspended organic materials, its colloidal nature and the homo-heterogenous media which permit its smooth flow into the plant system. The natural organic matter coupled with MWCNTs and fullerene $\left(\mathrm{C}_{70}\right)$ increases the hydrophilicity of nanomaterial. Carbon nanotubes are capable of penetrating plant seed and dramatically affect the seed germination and plant growth [45].

It has been demonstrated that SWCNTs of length less than $500 \mathrm{~nm}$ labelled with fluorescein isothiocyanate (FITC) penetrate the cell wall of the living plants by endocytosis. FITC alone is not easily taken up by the plants $[46,47]$ which means that both of them jointly facilitate the absorption/penetration of nanomaterials. Once the carbon nanomaterial is accumulated in the plant it may be transferred to the consumer. Tomato seedlings have been shown to absorb MWCNTs through seed and roots [41]. They enter the seed coat by piercing, increasing rapid absorption of water [42]. Carbon based nanomaterial can be taken up by the plants via root and distributed in the aerial parts. Their interaction with the chemicals present on the surface of root is not a driving force for their transport. They are transported by capillary action to places where the passage is wider than their size. When they reach a point where the passage is narrow carbon nanomaterial is accumulated and blocks the passage for nutrients to flow further. However, the carbon nanomaterial is genetically transmitted to the next generation $[44,48]$. The two consecutive generations of rice seeds grown showed the accumulation of $\mathrm{C}_{70}$ nanomaterial at different stages and different parts of the plant (Figure 1) followed by insertion of $\mathrm{C}_{70}$ nanomaterial in the first generation and then subsequent transmission to the progeny in the second generation. As a consequence of accumulation of nanomaterial of appropriate size in the plant cell the absorption/uptake of essential nutrients is hampered and hence the growth and flowering is delayed.

Serag et al. [11] have studied the effect of carbon nanomaterial at molecular level. They have shown that the diameter and length of SWCNTs are limiting factors for their penetration into the cell wall of the plants. If the size of carbon nanomaterial is too small it may diffuse and leak but if it is too large it may remain out of the cell and immobilised even if it has penetrated the plant cell wall. The chemically shortened SWCNTs have been shown to traverse through both cell wall and the cell membrane of tobacco and Catharanthus $[46,49,50]$. On the basis of high resolution transmission electron microscopy studies it has been shown that long MWCNTs (larger than $200 \mathrm{~nm}$ ) get accumulated in subcellular organelles while the shorter ones $(30-100 \mathrm{~nm})$ were found into vacuoles, nucleus and plastids [11,51].

Kole et al. [37] have demonstrated in an experiment with bitter melon, for the uptake of carbon nanomaterial that, with increasing concentration the hydrodynamic size of fullerol increases due to extensive hydrogen bonding as shown below. Every part of the plant was found to contain fullerol (Figure 2) which was also confirmed by FTIR spectral data. 
Table 1 Effects of carbon nanomaterials on plants

\begin{tabular}{|c|c|c|c|c|c|}
\hline Nanoparticle & Size $(\mathrm{nm})$ & Plant & Concentration & Effect & References \\
\hline \multirow[t]{2}{*}{$\mathrm{C}_{60}$ Fullerenes } & \multirow[t]{2}{*}{$1450-1900$} & Corn & \multirow[t]{2}{*}{$500 \mathrm{mg} \mathrm{kg}^{-1}$} & Reduced biomass & Torre-Roche et al. [36] \\
\hline & & Soybean & & Reduced biomass & Torre-Roche et al. [36] \\
\hline Fullerol $\left[\mathrm{C}_{60}(\mathrm{OH})_{20}\right]$ & $1.5 \pm 0.2-5.00 \pm 0.7$ & Bitter melon & $\begin{array}{l}0.943,4.72,9.43,10.88 \\
\text { and } 47.20 \mathrm{nM}\end{array}$ & $\begin{array}{l}\text { Increased biomass yield, water content, fruit length, fruit } \\
\text { number, and fruit fresh weight, increased two anticancerous } \\
\text { phytomedicines, cucurbitacin-B and lycopene, and two } \\
\text { antidiabetic phytomedicines, charantin and insulin }\end{array}$ & Kolle et al. [37] \\
\hline $\begin{array}{l}\text { Functionalized carbon } \\
\text { nanotube }\end{array}$ & 8 & Lettuce & $104,315,1750 \mathrm{mg} \mathrm{L}^{-1}$ & Reduced root length at longer exposure & Cañas et al. [34] \\
\hline $\begin{array}{l}\text { Functionalized single-walled } \\
\text { carbon nanotube }\end{array}$ & 8 & $\begin{array}{l}\text { Cabbage, carrot, lettuce, } \\
\text { onion, tomato }\end{array}$ & $9,56,315,1750 \mathrm{mg} \mathrm{L}^{-1}$ & No effect & Cañas et al. [34] \\
\hline \multirow[t]{9}{*}{ Multiwalled carbon nanotube } & & Zucchini & $1000 \mathrm{mg} \mathrm{L}^{-1}$ & Reduced biomass & Stampoulis et al. [38] \\
\hline & & Lettuce & $2000 \mathrm{mg} \mathrm{L}^{-1}$ & Reduced root length & Lin and Xing [39] \\
\hline & \multirow[t]{5}{*}{ Diameter range: $10-30$} & Rice & $20,40,80 \mathrm{mg} \mathrm{L}^{-1}$ & $\begin{array}{l}\text { Chromatin condensed inside the cytoplasm and caused cell } \\
\text { death, plasma membrane detachment from cell wall and cell } \\
\text { shrinkage }\end{array}$ & Tan and Lin [40] \\
\hline & & Tomato & $10-40 \mathrm{mg} \mathrm{L}^{-1}$ & $\begin{array}{l}\text { Significant increase in germination rate, fresh biomass, and } \\
\text { length of stem significantly enhanced moisture content inside } \\
\text { tomato seeds }\end{array}$ & Khodakovskaya et al. [41] \\
\hline & & $\begin{array}{l}\text { Corn, cucumber, radish, } \\
\text { rapeseed, ryegrass, lettuce }\end{array}$ & $2000 \mathrm{mg} \mathrm{L}^{-1}$ & No effect on germination & Lin and Xing [39] \\
\hline & & Ryegrass & $2000 \mathrm{mg} \mathrm{L}^{-1}$ & Increased root length & Lin and Xing [39] \\
\hline & & Zucchini & & No effect on the germination & Stampoulis et al. [38] \\
\hline & $\begin{array}{l}\text { Internal dimension: } \\
110-170\end{array}$ & Wheat & $100 \mathrm{mg} \mathrm{L}^{-1}$ & No significant effect on root or shoot growth & Wild and Jones [42] \\
\hline & $10-25$ & Tomato & $50-200 \mu \mathrm{g} \mathrm{L}^{-1}$ & Significant increase in plant height, flower and fruit formation & Khodakovskaya et al. [43] \\
\hline \multirow{4}{*}{$\begin{array}{l}\text { Single-walled carbon } \\
\text { nanotube }\end{array}$} & 1.19 (major), 18, 722 & Rice & $400 \mathrm{mg} \mathrm{L}^{-1}$ & Delayed flowering, decreased yield & Lin et al. [44] \\
\hline & 8 & Tomato & $104,315,1750 \mathrm{mg} \mathrm{L}^{-1}$ & Most sensitive in root reduction & Cañas et al. [34] \\
\hline & 8 & Cucumber onion, & $104,315,1750 \mathrm{mg} \mathrm{L}^{-1}$ & Increased root length & Cañas et al. [34] \\
\hline & 8 & Cabbage, carrot, lettuce & $104,315,1750 \mathrm{mg} \mathrm{L}^{-1}$ & No effect & Cañas et al. [34] \\
\hline
\end{tabular}




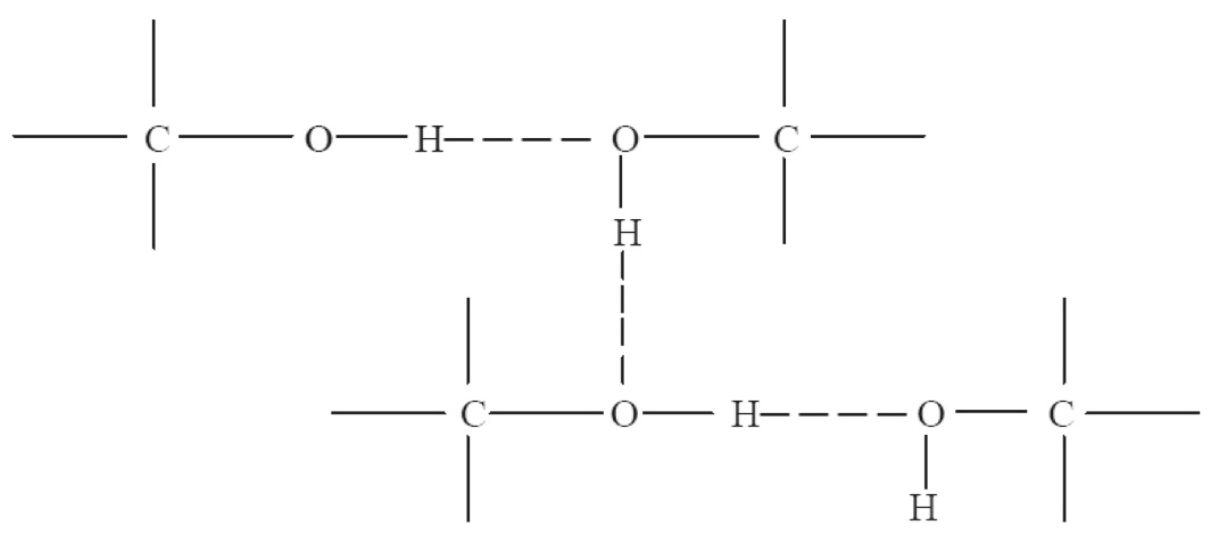

Hydrogen bonding in fullerol $\left[\mathrm{C}_{60}(\mathrm{OH})_{20}\right]$

Raman spectroscopy was used to locate the presence of carbon nanotubes in the reproductive organ of tomato plant. Clusters of carbon nanotubes were detected in the flower by the appearance of a Raman peak at $1587 \mathrm{~cm}^{-1}$ which was missing in the plant treated with activated charcoal or the control. It has been already demonstrated [52] on the basis of Raman photochemical and photoacoustic studies, that carbon nanotubes reach the leaves and fruits of tomato plants, irrigated with different concentrations of carbon nanotubes. Such nanomaterial might act as growth regulators of plants and may also increase crop production in cereal plants. However, an assessment of the toxicity of carbon nanotubes on environment and human system needs investigation.

\section{Response of carbon nanomaterials on plant growth and yield}

A large number of reports have shown the effect of carbon nanomaterials on both plant and mammalian cells [38,39,52-55]. It has been unanimously observed that highly functionalized carbon nanotubes exhibit remarkable reduction in toxicity $[56,57]$ even in cultured plant cells $[49,50,58,59]$.

\section{Effect of fullerene}

It was found that bitter melon seeds treated with fullerene increased the yield by 112 to $128 \%$. However, with large concentration of $\mathrm{C}_{60}$ the effect diminishes. The highest biomass increased up to $\sim 54 \%$. It confirms the absorption and translocation of fullerol in plants. All the cucurbitacin-B (74\%), lycopene (82\%), charantin (20\%) and insulin (91\%) were found to increase with respect to control. The bitter melon seeds treated with five different concentration of fullerol showed an enhancement in biomass, fruit yield and phytomedicine contents [37]. Fullerol of an appropriate size and concentration may, therefore, be used to increase the yield of cereal and fruit crop, nevertheless the adverse effect on the environment must be assessed before recommending its application in general.

\section{Effect of SWCNTS and MWCNTS}

The effects of functionalized and non-functionalized SWCNTs on six plants namely, cabbage, carrot, cucumber, lettuce, onion and tomato were investigated by Cañas et al. [34]. Root elongation was observed in onion and cucumber with the formation of sheets of carbon nanotubes. It is surprising that neither of the carbon nanotubes entered the root of the plant. Root elongation in such plants is of no use because it is not edible. The cabbage and carrot were unaffected. Root elongation in lettuce and tomato was inhibited. Contradicting reports have been received regarding the influence of carbon nano tube on various plants. Khodakovskaya et al. [41] have shown, from their experiments on similar plants, that increased water uptake by seeds increased their germination.

Experiment on suspension rice cells with MWCNTs showed that it induced the production and accumulation of reactive oxygen species (ROS) as a consequence of which, plant cells die [60]. It also decreases the dry weight, chlorophyll content and the activity of superoxide dismutase (SOD) in Arabidopsis suspension cells [35]. The reason for all cell damage and eventual death is ascribed to apoptosis or necrosis. In case of interaction of MWCNTs with rice suspension, cells had aggregated in self defence to prevent the other cells from damage by them [60]. Such defensive mechanism sometime forces the plants to undergo 


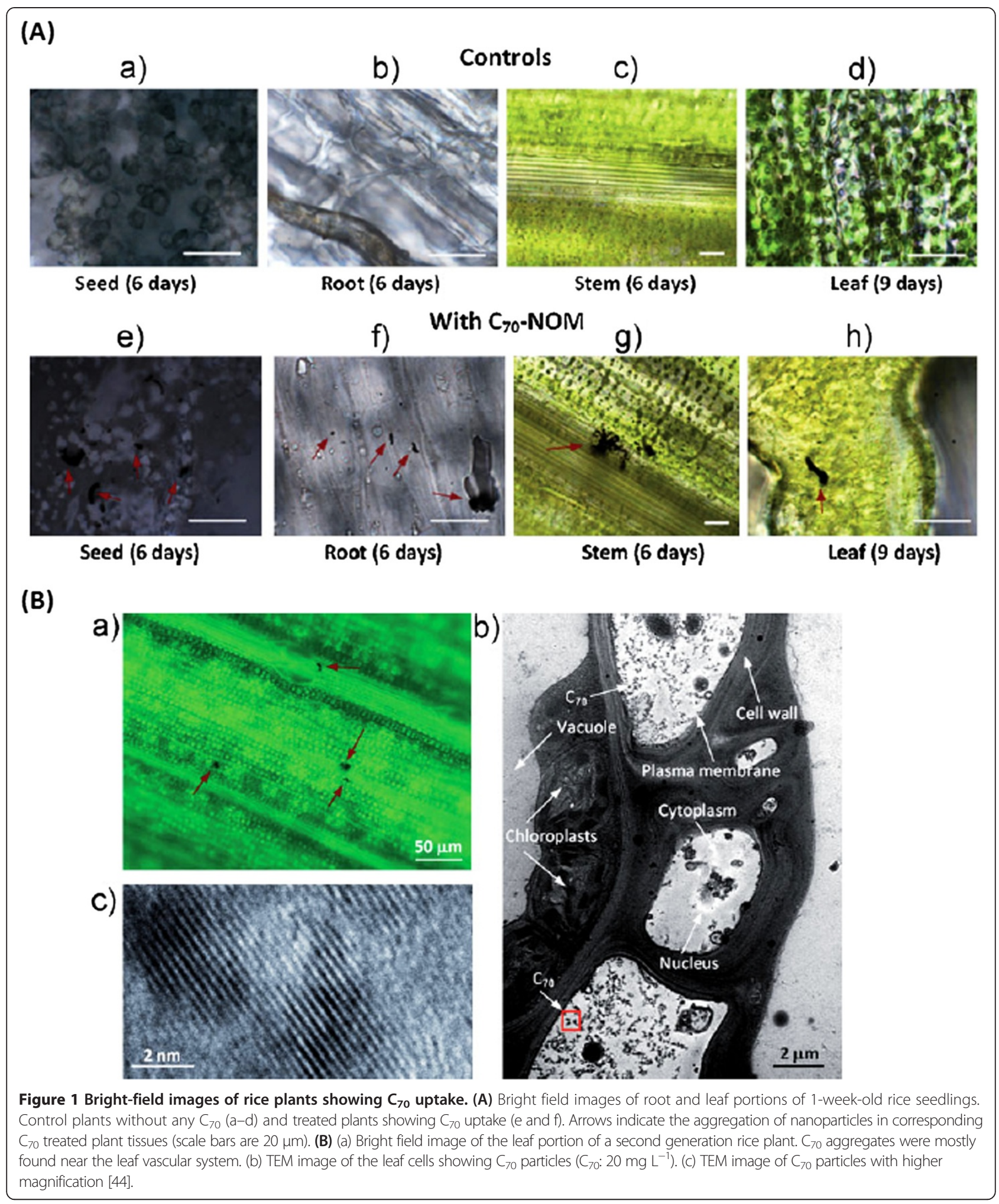

certain changes in their activity such as thickening of the cell wall to avoid penetration by MWCNTs or other unwanted foreign particles. The rice seeds were germinated after their treatment with SWCNTs, MWCNTs and $\mathrm{C}_{70}$ in presence of nano-organic material and harvested after six months. They were further grown as second generation seed and examined for carbon nanomaterial in different parts of the plant. The carbon nanomaterials were 


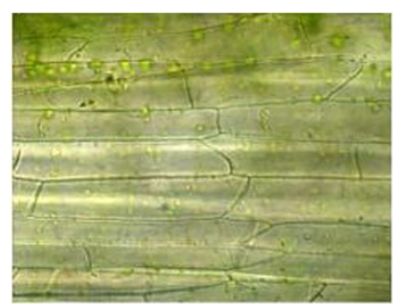

Co-Petiole

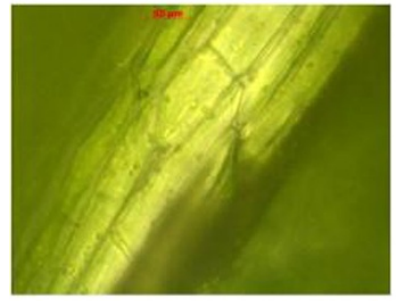

C0-Leaf

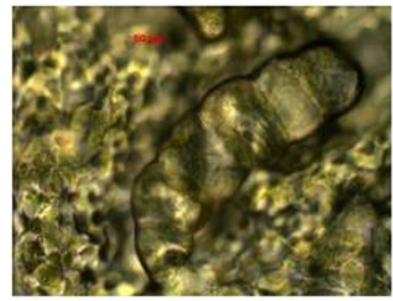

C0-Flower

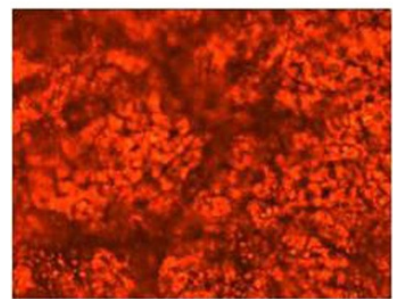

C0-Fruit

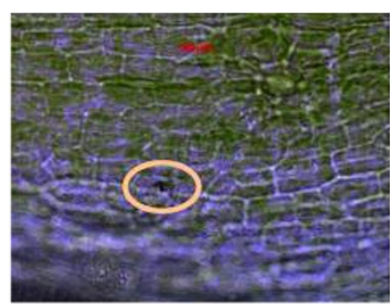

C3-Petiole

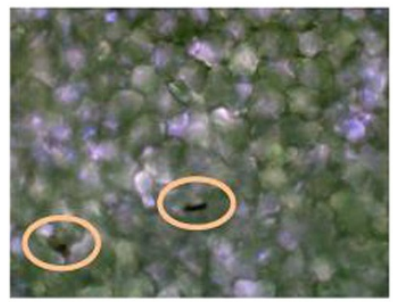

C2-Leaf

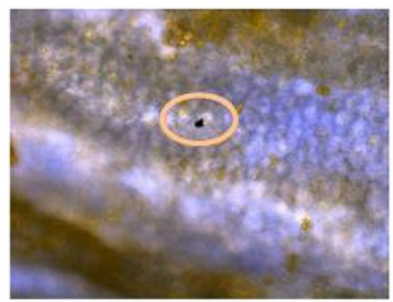

C3-Flower

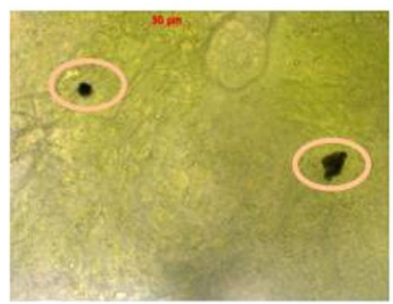

C2-Fruit

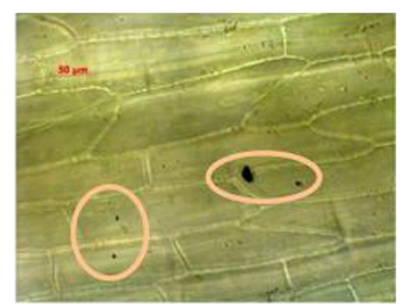

C5-Petiole

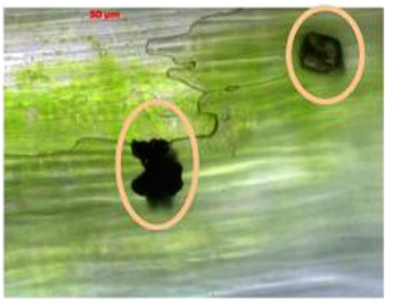

C4-Leaf

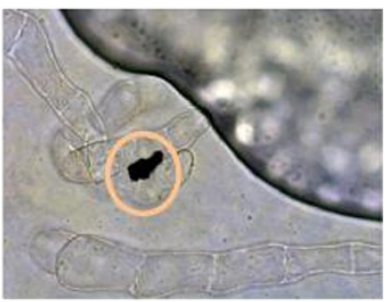

C4-Flower

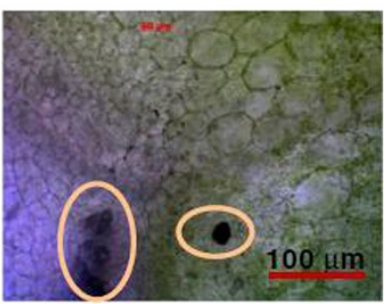

C4-Fruit

Figure 2 Biodistribution of fullerols in plant organs including petioles, leaves, flowers, and fruits. The circles highlight black aggregates which were later confirmed by FTIR as fullerols [37].

found as black aggregate in the following chronological order:

\section{Seed $>$ root $>$ stem $>$ leaf}

This proved that $C_{70}$ is transmitted to the next generation of the plant which was further confirmed from IR and Raman spectral data. However, after sometime no $\mathrm{C}_{70}$ was present in root showing complete transport while uptake of MWCNTs was almost insignificant. It is normally accumulated in the root and delays the germination of rice seeds by 1 month [60].

It is known that MWCNTs do not have any significant effect on seed germination in a variety of plants even when treated for five days with as high concentration as $2000 \mathrm{mg} \mathrm{L}^{-1}$ [39]. A similar observation was made by Wild and Jones [42] in case of wheat root. However, conflicting reports have been received about tomato seed germination with as little MWCNTs as $10-40 \mathrm{mgL}^{-1}$ [41]. Perhaps the effect of such nanomaterial on different plants is different but it may change in the presence of other substances or the organic material already present in the medium.

Khodakovskaya et al. [43] have demonstrated the influence of MWCNTs on the tomato plant from the germination to the flowering stage. They observed that when the tomato plants were treated separately with both activated charcoal and carbon nanotubes the height was increased in the plants treated with carbon nanotubes only. It is surprising to note that tomato plants treated with carbon nanotubes bore twofold flowers compared to the control and those treated with activated charcoal. It shows potential of increasing the tomato production by $200 \%$. Since at $50 \mu \mathrm{g} \mathrm{mL} \mathrm{m}^{-1}$ dose it had the same 
influence as that obtained by $200 \mu \mathrm{g} \mathrm{mL}^{-1}$, a minimum dose of $50 \mu \mathrm{g} \mathrm{mL} \mathrm{m}^{-1}$ may be fixed. It may be inferred from the findings that carbon nanotubes influence the reproductive system although the mechanism is yet to be understood.

The maize seedlings grown in agar gel, treated by different concentrations of pristine MWCNTs, had dramatic influence on water uptake and growth [61]. Analysis of seedlings showed the presence of nearly all elements of $3^{\text {rd }}$ $(\mathrm{Na}, \mathrm{Mg}, \mathrm{Al}, \mathrm{Si}, \mathrm{P}, \mathrm{S}$ and $\mathrm{Cl})$ and $4^{\text {th }}(\mathrm{K}, \mathrm{Ca}, \mathrm{Ga}, \mathrm{Ge}, \mathrm{As}, \mathrm{Se}$ and $\mathrm{Br}$ ) period without much variation when compared with control or minimum MWCNTs concentration of $5 \mathrm{mgL}^{-1}$. The authors have shown changes in the morphology of MWCNTs after the addition of $\mathrm{Fe}^{2+}$ and $\mathrm{Fe}^{3+}$ in separate experiments. Since $\mathrm{Fe}^{2+}$ in aqueous medium is immediately oxidised to $\mathrm{Fe}^{3+}$, the effect of addition of $\mathrm{Fe}^{2+}$ will exactly be the same as that of $\mathrm{Fe}^{3+}$. However, $\mathrm{Fe}^{2+}$ can be stabilized in acidic medium.

In one of the experiments Mondal et al. [62] have shown that MWCNTs of approximately $30 \mathrm{~nm}$ diameter enhance the rate of germination and growth of Brassica juncea. Likewise, $\mathrm{TiO}_{2}$ has also been reported to enhance the rate of germination and strength of spinach seedlings [63]. Later it was found that [41] such nanoparticles increase the moisture content of the seeds, perhaps owing to adsorption, which in turn, may be absorbed by the seedling. The oxidized carbon nanotubes had better effect on the seed germination than the carbon nanotubes alone, although the concentration of the oxidized carbon nanotubes was much lower. Quite good results were obtained with oxidized MWCNTs $\left(2.3 \times 10^{-3} \mathrm{mg} \mathrm{mL}^{-1}\right)$ but when the concentration exceeds $46 \times 10^{-3} \mathrm{mg} \mathrm{mL}^{-1}$ both pure and oxidized MWCNTs inhibit the germination of mustard seeds. It clearly indicated that the rate of growth is concentration dependent. This technique may, therefore, be applied to increase the rate of germination of crop plants.

It has been suggested that electrical conductivity of a solution increases when plant tissues are immersed in carbon nanomaterials. This is correct up to a certain limit above which the conductance becomes constant because, as the concentration [63] of leached salts, amino acids, potassium, phosphate, sugar and carbohydrates increases, the freedom of movement of these molecules and ions decreases. Aquaporins are water channels which selectively allow water molecules to flow in and out of the tissue but also reject certain substances in order to maintain equilibrium. It is concluded that pre -soaking of seeds with very low concentration of oxidized MWCNTs have positive effect on seed germination.

\section{Effect of industrial grade MWCNTs}

Taunith, a carbon nanotubes material containing industrialized MWCNTs has been shown to stimulate the growth of Onobrychis arenaria plant and enhance peroxidase activity [64]. It suggests that the accumulation and onward translocation of CNTs in leaves and roots occurs. The increase in peroxidase activity is associated with the oxidative stress caused by CNTs. Elena et al. [64] have shown that MWCNTs accumulated at the root surface quite often penetrate the epidermal cells causing injury as a result of which the level of peroxidase activity is elevated. The accumulation of CNTs has been confirmed from TEM images of different parts of the plant.

Recently, Miralles et al. [65] have studied the effect of industrial grade MWCNTs $\left(2560 \mathrm{mg} \mathrm{L}^{-1}\right)$ and their impurities on alfalfa and wheat germination. The nanomaterial was functionalized with $\mathrm{Fe}_{3} \mathrm{O}_{4}$ nanoparticles in plant tissue. It was observed that carbon nanotube is adsorbed on to the root surface with significant root elongation in both alfalfa and wheat but with insignificant uptake and translocation [65].

It is important to note that in some cases $[66,67]$ the carbon nanotubes were mixed with catalysts such as $\mathrm{Al}_{2} \mathrm{O}_{3}$ and $\mathrm{Fe}$, suspected to contain $\mathrm{Fe}^{\mathrm{o}}, \mathrm{Fe}_{2} \mathrm{O}_{3}, \mathrm{Fe}_{3} \mathrm{O}_{4}$ or dissolved $\mathrm{Fe}^{2+}$ or $\mathrm{Fe}^{3+}$ ions. It should be remembered that iron metal as nanoparticle may be present but $\mathrm{Fe}^{2+} / \mathrm{Fe}^{3+}$ may be there only in equilibrium with their anions like $\mathrm{Cl}^{-}, \mathrm{Br}^{-}, \mathrm{I}^{-}, \mathrm{SO}_{4}^{2-}, \mathrm{CO}_{3}^{2-}, \mathrm{CH}_{3} \mathrm{COO}^{-}$and similarly the oxides of iron such as $\mathrm{FeO}, \mathrm{Fe}_{2} \mathrm{O}_{3}$ and $\mathrm{Fe}_{3} \mathrm{O}_{4}$ are equally likely to be present. On the other hand $\mathrm{Al}_{2} \mathrm{O}_{3}$ in water can persist only as $\mathrm{Al}(\mathrm{OH})_{3}$ according to the following reaction:

$$
\mathrm{Al}_{2} \mathrm{O}_{3}+{ }_{3} \mathrm{H}_{2} \mathrm{O} \rightarrow 2 \mathrm{Al}(\mathrm{OH})_{3}
$$

The authors [65] suggest that their carbon nanotubes contain $\mathrm{Fe} / \mathrm{Al}_{2} \mathrm{O}_{3}$ and the FTIR exhibits a peak at $1560 \mathrm{~cm}^{-1}$ showing $\mathrm{v}(\mathrm{C}=\mathrm{C})$ for graphite structure. The carbon or carbon nanotubes, in elemental form can not exhibit $\mathrm{v}(\mathrm{C}=\mathrm{C})$ because IR spectrum can detect the frequency of functional groups not that of an element. This $v(C=C)$ at $1560 \mathrm{~cm}^{-1}$ indicates the presence of some organic compound which remained undetected. If this peak is assigned to $\mathrm{v}(\mathrm{C}=\mathrm{C})$, it confirms the presence of alkene such as acetylene or ethylene or their derivative. The ester group indicated is actually a ketonic group $\left(\mathrm{R}_{2} \mathrm{C}=\mathrm{O}\right)$. The ester group is -COOR and hence, the assignment is ambiguous. It has been shown in this case [65] that the rate of increased germination is mainly due to contamination and not due to carbon nanotubes alone. The enhanced wheat germination rate with respect to that of alfalfa has been ascribed to ease of penetration of carbon nanotube in the seed along with water. Since wheat seed is relatively softer than that of alfalfa the penetration and bioavailability of carbon nanotube in alfalfa is slow and hence the effect is low and delayed. Cañas 
et al. [34] have shown that carbon nanotube enhances the root growth of cucumber and onion seeds but affects adversely in tomato, lettuce, carrot and cabbage. It has also been suggested that carbon nanotube in tomato altered the gene expression thereby activating the growth [34]. The impurity $\left(\mathrm{Fe}\right.$ or $\left.\mathrm{Fe}_{3} \mathrm{O}_{4}\right)$ in carbon nanotube influences the plant growth. Although $\mathrm{Fe}$ nanoparticles are not toxic to pumpkin $[68,69]$ they inhibit the germination and growth in flax, ryegrass and barley [70].

Pristine carbon nanotubes have been found to induce toxicity in plants. SWCNTs are known to produce toxicity in rice and Arabidopsis leading to the death of $25 \%$ of protoplast in $6 \mathrm{~h}$ [55]. MWCNTs were found to reduce the biomass of Cucurbita pepo plants [38]. However, effort is to be made to prevent the damage of plant cell from carbon nanomaterials [38]. Effect of carbon nanotubes on growth and development of tomato seedling germinated in Murashige and Skoog medium has been thoroughly studied [41] using TEM, TGA and Raman spectroscopic data in a concentration range between $10-40 \mu \mathrm{gL}^{-1}$.

\section{Carbon nanotubes and pesticides}

Effect of carbon nano materials on pesticide residue in zucchini, corn, tomato and soybean has been investigated by Torre-Roche et al. [36]. It was found that pesticide residue uptake by the above plants was reduced in presence of carbon nanotubes. Different parts of the plant had different quantum of chlordane and DDT accumulated which were reduced when exposed to MWCNTs. The quantity of it varies with species to species, dispersion, mobility and transport of the nanomaterials. Selective carbon nano materials in controlled quantity are capable of activating physiological processes in plants. Root growth in onion, cucumber and ryegrass and plant growth of tomato $[34,39,52,71]$ has been shown by carbon nanotubes. They are also helpful in slow release of pesticides [72].

\section{Conclusion}

Carbon/fullerene nanotechnology is a rapidly growing area of research which finds use in plant, medicine and engineering. Carbon nanotubes (single-wall carbon nanotubes and multi-wall carbon nanotubes) in many cases can penetrate the seed coat and plant cell wall which depends on their size, concentration and solubility. The size of carbon nanotubes alone is of great significance in agriculture and biotechnology. The penetration of carbon nanotubes into the plant system can bring changes in metabolic functions leading to an increase in biomass, fruit/grain yield. The nanobiotechnology may be helpful for the advancement of agriculture and plant sciences. Although in some cases, carbon nanomaterials are known to be phytotoxic their concentration may be controlled within the permissible limit to prevent any damage. Their bioavailability must be assessed if they pose risk to man and animals. The future prospect of carbon nanomaterials is fairly bright as it is a low cost solution to increase the crop production and fruit manifold.

\section{Competing interests}

The authors declare that they have no competing interests.

\section{Authors' contributions}

$\mathrm{AH}$ gathered the research data. $\mathrm{AH}$ and $\mathrm{KSS}$ analyzed these data findings and wrote this review paper. Both authors read and approved the final manuscript.

\section{Acknowledgement}

Authors are thankful to publishers for permission to adopt figures in this review.

\section{Author details}

'Department of Biology, College of Natural and Computational Sciences, University of Gondar, P.O. Box 196, Gondar, Ethiopia. ${ }^{2}$ Department of Chemistry, College of Natural and Computational Sciences, University of Gondar, P.O. Box 196, Gondar, Ethiopia.

Received: 25 January 2014 Accepted: 14 April 2014

Published: 25 April 2014

\section{References}

1. Cheremisinoff PN, Angelo CM: Carbon Adsorption Applications, Carbon Adsorption Handbook. Inc. Ann Arbor, Michigan: Ann Arbor Science Publishers; 1980

2. Ugarte D: Curling and closure of graphitic networks under electron-beam irradiation. Nature 1992, 359:707-709.

3. Wang BC, Wang HW, Chang JC, Tso HC, Chou YM: More spherical large fullerenes and multi-layer fullerene cages. J Mol Struct Theochem 2001, 540:171-176.

4. Warheit DB: Nanoparticles: health impacts? Mater Today 2004, 7:32-35.

5. Upadhyayula VKK, Deng S, Mitchell MC, Smith GB: Application of carbon nanotube technology for removal of contaminants in drinking water: a review. Sci Total Environ 2009, 408:1-13.

6. Zhang W, Zhang Z, Zhang Y: The application of carbon nanotubes in target drug delivery systems for cancer therapies. Nano Res Lett 2011, 6:555.

7. Kostarelos K, Lacerda L, Pastorin G, Wu W, Wieckowski S, Luangsivilay J, Godefroy S, Pantarotto D, Briand JP, Muller S, Prato M, Bianco A: Cellular uptake of functionalized carbon nanotubes is independent of functional group and cell type. Nat Nanotechnol 2007, 2:108-113.

8. Ali-Boucetta H, Al-Jamal KT, Müller KH, Li S, Porter AE, Eddaoudi A, Prato M, Bianco A, Kostarelos K: Cellular uptake and cytotoxic impact of chemically functionalized and polymer-coated carbon nanotubes. Small 2011, 7:3230-3238.

9. Cui D, Zhang H, Sheng J, Wang Z, Toru A, He R, Tetsuya O, Gao F, Cho H-S, Cho S, Huth C, Hu H, Pauletti GM, Shi D: Effects of CdSe/ZnS quantum dots covered multi-walled carbon nanotubes on murine embryonic stem cells. Nano Biomed Eng 2010, 2:236-244.

10. Lacerda L, Russier J, Pastorin G, Herrero MA, Venturelli E, Dumortier H, Al-Jamal KT, Prato M, Kostarelos K, Bianco A: Translocation mechanisms of chemically functionalised carbon nanotubes across plasma membranes. Biomaterials 2012, 33:3334-3343.

11. Serag MF, Kaji N, Habuchi S, Bianco A, Baba Y: Nanobiotechnology meets plant cell biology: carbon nanotubes as organelle targeting nanocarriers. RSC Adv 2013, 3:4856-4862.

12. Dugan LL, Turetsky DM, Du C, Lobner D, Wheeler M, Almli CR, Shen Clifton KF, Luh TY, Choi DW, Lin TS: Carboxyfullerenes as neuroprotective agents. Proc Natl Acad Sci U S A 1997, 94:9434-9439.

13. Dugan LL, Lovett EG, Quick KL, Lotharius J, Lin T, O'Malley KL: Fullerene based antioxidants and neurodegenerative disorders. Parkinson Relat Disord 2001, 7:243-246. 
14. Gharbi N, Pressac M, Hadchouel M, Szwarc H, Wilson SR, Moussa F: Fullerene is a powerful antioxidant in vivo with no acute or subacute toxicity. Nano Lett 2005, 5:2578-2585.

15. Byon HR, Choi HC: Network single-walled carbon nanotube-field effect transistors (SWNT FETs) with increased Schottky contact area for highly sensitive biosensor applications. J Am Chem Soc 2006, 128:2188-2189.

16. Kim SN, Rusling JF, Papadimitrakopoulos F: Carbon nanotubes for electronic and electrochemical detection of biomolecules. Adv Mater 2007, 19:3214-3228.

17. Morones JR, Elechiguerra JL, Camacho A, Holt K, Kouri JB, Ramirez JT, Yacaman MJ: The bactericidal effect of silver nanoparticles. Nanotechno 2005, 16:2346-2353.

18. Cherukuri P, Gannon CJ, Leeuw TK, Schmidt HK, Smalley RE, Curley SA, Weisman RB: Mammalian pharmacokinetics of carbon nanotubes using intrinsic near-infrared fluorescence. Proc Natl Acad Sci U S A 2006, 103:18882-18886.

19. Welsher K, Liu Z, Daranciang D, Dai H: Selective probing and imaging of cells with single walled carbon nanotubes as near-infrared fluorescent molecules. Nano Lett 2008, 8:586-590.

20. Heller DA, Baik S, Eurell TE, Strano MS: Singlewalled carbon nanotube spectroscopy in live cells: towards long-term labels and optical sensors. Adv Mater 2005, 17:2793-2799.

21. Cherukuri P, Bachilo SM, Litovsky SH, Weisman RB: Near-infrared fluorescence microscopy of single-walled carbon nanotubes in phagocytic cells. J Am Chem Soc 2004, 126:15638-15639.

22. Leeuw TK, Reith RM, Simonette RA, Harden ME, Cherukuri P, Tsyboulski DA, Beckingham KM, Weisman RB: Single-walled carbon nanotubes in the intact organism: near-IR imaging and biocompatibility studies in Drosophila. Nano Lett 2007, 7:2650-2654.

23. Jin $\mathrm{H}$, Heller DA, Strano MS: Single-particle tracking of endocytosis and exocytosis of single-walled carbon nanotubes in NIH-3 T3 cells. Nano Lett 2008, 8:1577-1585.

24. Poland CA, Duffin R, Kinloch I, Maynard A, Wallace WAH, Seaton A, Stone V, Brown S, MacNee W, Donaldson K: Carbon nanotubes introduced into the abdominal cavity of mice show asbestos-like pathogenicity in a pilot study. Nat Nanotechno 2008, 3:423-428.

25. Kam NWS, Jessop TC, Wender PA, Dai HJ: Nanotube molecular transporters: Internalization of carbon nanotube-protein conjugates into mammalian cells. J Am Chem Soc 2004, 126:6850-6851.

26. Dumortier H, Lacotte S, Pastorin G, Marega R, Wu W, Bonifazi D, Briand JP, Prato M, Muller S, Bianco A: Functionalized carbon nanotubes are noncytotoxic and preserve the functionality of primary immune cells. Nano Lett 2006, 6:1522-1528.

27. Schipper ML, Nakayama-Ratchford N, Davis CR, Kam NWS, Chu P, Liu Z, Sun X Dai H, Gambhir SS: A pilot toxicology study of single-walled carbon nanotubes in a small sample of mice. Nat Nanotech 2008, 3:216-221.

28. Wu P, Chen X, Hu N, Tam UC, Blixt O, Zettl A, Bertozzi CR: Biocompatible carbon nanotubes generated by functionalization with glycodendrimers. Angew Chem Int Ed 2008, 47:5022-5025.

29. Jeong GH, Farajian AA, Hatakeyama R, Hirata T, Yaguchi T, Tohji K, Mizuseki $\mathrm{H}$, Kawazoe Y: Cesium encapsulation in single-walled carbon nanotubes via plasma ion irradiation: Application to junction formation and $a b$ initio investigation. Phys Rev B 2003, 68:075410.

30. Li ப, Khlobystov AN, Wiltshire JG, Briggs GAD, Nicholas RJ: Diameter-selective encapsulation of metallocenes in single-walled carbon nanotubes. Nat Mater 2005, 4:481-485.

31. Kaneko T, Okada T, Hatakeyama R: DNA encapsulation inside carbon nanotubes using micro electrolyte plasmas. Contrib Plasma Phys 2007, 47:57-63.

32. Donaldson K, Aitken R, Tran L, Stone V, Duffin R, Forrest G, Alexander A: Carbon nanotubes: a review of their properties in relation to pulmonary toxicology and workplace safety. Toxicol Sci 2006, 92:5-22.

33. Ke PC, Qiao R: Carbon nanomaterials in biological systems. J Phys Condens Matter 2007, 19:373101-373125.

34. Cañas JE, Long M, Nations S, Vadan R, Dai L, Luo M, Ambikapathi R, Lee EH, Olszyk D: Effects of functionalized and non functionalized single-walled carbon nanotubes on root elongation of select crop species. Environ Toxicol Chem 2008, 27:1922-1931.

35. Lin C, Fugetsu B, Su Y, Watari F: Studies on toxicity of multi-walled carbon nanotubes on Arabidopsis T87 suspension cells. J Hazard Mater 2009, 170:578-583.
36. Torre-Roche RDL, Hawthorne J, Deng Y, Xing B, Cai W, Newman LA, Wang Q, $\mathrm{Ma} X$, Hamdi $\mathrm{H}$, White JC: Multiwalled carbon nanotubes and $\mathrm{C}_{60}$ fullerenes differentially impact the accumulation of weathered pesticides in four agricultural plants. Environ Sci Technol 2013, 47:12539-12547.

37. Kole C, Kole P, Randunu KM, Choudhary P, Podila R, Ke PC, Rao AM, Marcus RK: Nanobiotechnology can boost crop production and quality: first evidence from increased plant biomass, fruit yield and phytomedicine content in bitter melon (Momordica charantia). BMC Biotechno 2013, 13:37.

38. Stampoulis D, Sinha SK, White JC: Assay-dependent phytotoxicity of nanoparticles to plants. Environ Sci Technol 2009, 43:9473-9479.

39. Lin D, Xing B: Phytotoxicity of nanoparticles, Inhibition of seed germination and root growth. Environ Pollut 2007, 150:243-250.

40. Tan XM, Lin C, Fugetsu B: Studies on toxicity of multiwalled carbon nanotubes on suspension rice cells. Carbon 2009, 47:3479-3487.

41. Khodakovskaya M, Dervishi E, Mahmood M, Xu Y, Li Z, Watanabe F, Biris AS: Carbon nanotubes are able to penetrate plant seed coat and dramatically affect seed germination and plant growth. ACS Nano 2009, 3:3221-3227.

42. Wild $\mathrm{E}$, Jones $\mathrm{KC}$ : Novel method for the direct visualization of in vivo nanomaterials and chemical interactions in plants. Environ Sci Technol 2009, 43:5290-5294.

43. Khodakovskaya MV, Kim BS, Kim JN, Alimohammadi M, Dervishi E, Mustafa T, Cernigla CE: Carbon nanotubes as plant growth regulators: effects on tomato growth, reproductive system, and soil microbial community. Small 2013, 14:115-123.

44. Lin S, Reppert J, Hu Q, Hudson JS, Reid ML, Ratnikova TA, Rao AM, Luo H, Ke PC: Uptake, translocation, and transmission of carbon nanomaterials in rice plants. Small 2009, 5:1128-1132

45. Khodakovskaya MV, de Silva K, Biris AS, Dervishi E, Villagarcia H: Carbon nanotubes induce growth enhancement of tobacco cells. ACS Nano 2012, 6:2128-2135.

46. Liu Q, Chen B, Wang Q, Shi X, Xiao Z, Lin J, Fang X: Carbon nanotubes as molecular transporters for walled plant cells. Nano Lett 2009, 9:1007-1010.

47. Samaj J, Baluska F, Voigt B, Schlicht M, Volkmann D, Menzel D: Endocytosis, actin cytoskeleton, and signaling. Plant Physiol 2004, 135:1150-1161.

48. Rico CM, Majumdar S, Duarte-Gardea M, Peralta-Videa JR, Gardea-Torresdey JL: Interaction of nanoparticles with edible plants and their possible implications in the food chain. J Agric Food Chem 2011, 59:3485-3498.

49. Serag MF, Kaji N, Venturelli E, Okamoto Y, Terasaka K, Tokeshi M, Mizukami H, Ugent KB, Bianco A, Baba Y: A functional platform for controlled subcellular distribution of carbon nanotubes. ACS Nano 2011, 5:9264-9270.

50. Serag MF, Braeckmans K, Habuchi S, Kaji N, Bianco A, Baba Y. Spatiotemporal visualization of subcellular dynamics of carbon nanotubes. Nano Lett 2012, 12:6145-6151.

51. Serag MF, Kaji N, Gaillard C, Okamoto Y, Terasaka K, Jabasini M, Tokeshi M, Mizukami H, Bianco A, Baba Y: Trafficking and subcellular localization of multiwalled carbon nanotubes in plant cells. ACS Nano 2011, 5:493-499.

52. Khodakovskaya M, de Silva K, Nedosekin D, Dervishi E, Biris AS, Shashkov EV, Galanzha El, Zharov VP: Complex genetic, photothermal, and photoacoustic analysis of nanoparticle-plant interactions. Proc Natl Acad Sci U S A 2011, 108:1028-1033.

53. Schwab F, Bucheli TD, Lukhele LP, Magrez A, Nowack B, Sigg L, Knauer K: Are carbon nanotube effects on green algae caused by shading and agglomeration? Environ Sci Technol 2011, 45:6136-6144.

54. Oleszczuk P, Josko I, Xing BS: The toxicity to plants of the sewage sludges containing multiwalled carbon nanotubes. J Hazard Mater 2011, 186:436-442.

55. Shen CX, Zhang QF, Li J, Bi FC, Yao N: Induction of programmed cell death in Arabidopsis and rice by single-wall carbon nanotubes. Am J Bot 2010, 97:1602-1609.

56. Sayes CM, Liang F, Hudson JL, Mendez J, Guo W, Beach JM, Moore VC, Doyle CD, West JL, Billups WE, Ausman KD, Colvin VL: Functionalization density dependence of single-walled carbon nanotubes cytotoxicity in vitro. Toxicol Lett 2006, 161:135-142.

57. Kostarelos K, Bianco A, Prato M: Promises, facts and challenges for carbon nanotubes in imaging and therapeutics. Nat Nanotechnol 2009, 4:627-633.

58. Serag MF, Kaji N, Tokeshi M, Bianco A, Baba Y: The plant cell uses carbon nanotubes to build tracheary elements. Integr Biol 2012, 4:127-131.

59. Serag MF, Kaji N, Tokeshi M, Baba Y: Introducing carbon nanotubes into living walled plant cells through cellulase-induced nanoholes. RSC Advances 2012, 2:398-400. 
60. Xm T, Lin C, Fugetsu B: Studies on toxicity of multi-walled carbon nanotubes on suspension rice cells. Carbon 2009, 47:3479-3487.

61. Tiwari DK, Dasgupta-Schubert N, Villaseñor Cendejas N, Villegas J, Carreto Montoya L, Borjas García SE: Interfacing carbon nanotubes (CNT) with plants: enhancement of growth, water and ionic nutrient uptake in maize (Zea mays) and implications for nanoagriculture. Appl Nanosci 2013, : DOI 10.1007/s13204-013-0236-7.

62. Mondal A, Basu R, Das S, Nandy P: Beneficial role of carbon nanotubes on mustard plant growth: an agricultural prospect. Nanopart Res 2011, 13:4519-4528.

63. Zheng L, Hong FS, Lu SP, Liu C: Effect of nano- $\mathrm{TiO}_{2}$ on strength of naturally aged seeds and growth of spinach. Biol Trace Elem Res 2005, 104:83-91.

64. Elena S, Gusev A, Zaytseva O, Sheina O, Tkachev A, Kuznetsova E, Lazareva E, Onishchenko G, Feofanov A, Kirpichnikov M: Uptake and accumulation of multiwalled carbon nanotubes change the morphometric and biochemical characteristics of Onobrychis arenaria seedlings. Fron Chem Sci Eng 2012, 6:132-138.

65. Miralles $\mathrm{P}$, Johnson E, Tamara LC, Harris AT: Multiwalled carbon nanotubes in alfalfa and wheat: toxicology and uptake. $J R$ Soc Interf 2012, 9:3514-3527.

66. Liu X, Gurel V, Morris D, Murray DW, Zhitkovich A, Kane AB, Hurt RH: Bioavailability of nickel in single-wall carbon nanotubes. Adv Mater 2007, 19:2790-2796

67. Liu S, Wei L, Hao L, Fang N, Chang MW, Xu R, Yang Y, Chen Y: Sharper and faster 'nano darts' kill more bacteria: a study of antibacterial activity of individually dispersed pristine single-walled carbon nanotube. ACS Nano 2009, 3:3891-3902.

68. Zhu H, Han J, Xiao JQ, Jin Y: Uptake, translocation, and accumulation of manufactured iron oxide nanoparticles by pumpkin plants. J Environ Monit 2008, 10:713-717.

69. González-Melendi P, Fernández-Pacheco R, Coronado MJ, Corredor E, Testillano PS, Risueño MC, Marquina C, Ibarra MR, Rubiales D, Pérez-deLuque A: Nanoparticles as smart treatment-delivery systems in plants: assessment of different techniques of microscopy for their visualization in plant tissues. Ann Bot 2008, 101:187-195.

70. El-Temsah YS, Joner EJ: Impact of Fe and Ag nanoparticles on seed germination and differences in bioavailability during exposure in aqueous suspension and soil. Environ Toxicol 2010, 27:42-49.

71. Villagarcia H, Dervishi E, de Silva K, Biris AS, Khodakovskaya M: Surface chemistry of carbon nanotubes impacts the growth and expression of water channel protein in tomato plants. Small 2012, 8:2328-2334.

72. Perez-de-Luque A, Rubiales D: Nanotechnology for parasitic plant control. Pest Manag Sci 2009, 65:540-545.

\section{Submit your next manuscript to BioMed Central and take full advantage of:}

- Convenient online submission

- Thorough peer review

- No space constraints or color figure charges

- Immediate publication on acceptance

- Inclusion in PubMed, CAS, Scopus and Google Scholar

- Research which is freely available for redistribution 